\title{
Importance of the Religious Values in Family Development
}

\author{
Dr. Pisal Anita Sambhaji, \\ Assistant Professor, Bharati Vidyapeeth University, Social Science centre, Pune.
}

\begin{abstract}
India is the different country in world. India is a religion country and almost all people believe in religious values and their influence on family development in India. Family values are the foundation of the children to share your family values and traditions with your children. Family is the extremely important component of India culture. Families are valued highly and are a part of an individual life until death. Traditional family values that all fall under the "love task" include all our relationship. Traditional family values usually include such as religion, marriage, communication, traditions, morals, holidays interactions with relatives. Often when people get married they take in their older relatives and other realties provider support of them. Many people don't think about their family values until a crisis that forces them to make decision that may go against their beliefs. While they may have faced with the realization that something doesn't quite fit in to what they believe in family values are important on many different levels of the family structure. Families with defined values are able to stand strong on their views despite other people effort to break through with opposing beliefs. He process of transmission of the socialization process empirical studies on adolescent fully activities of youth values are analyzed development of ethical principal founded in religious traditions, text, belief. In contrast to personal values, religious-based values are based on scriptures and a religions established norms. A value is an individual assumption of ethical value that can be from basis for action. A principal value is a foundation upon which other values and measure of integrity are based. As such values reflect a person's sense of right and wrong or what "ought" to be "equal right for all" people should be treated with respect and dignity" are representative of values, values tend to influence attitudes and behavior and help solve common human problems for survival by comparative ranking of value. The religion is a highly personal thing yet it has a social role to play.
\end{abstract}

\section{INTRODUCTION}

India is religious country and all most all the people sincerely believe in religion. Religion touches very corner of the society and the scull of all the ordinary people. Hindu Religion influences society is by the values that are taught by most important leaders of the religion concerned. It is assumed that these values will influence actual behavior and thus the functioning of society. It has been powerful agency in society and performs many important of social function.

The religion values are good impact on the personality development of the youth. Extended families and communities function as buffers against economic hardships caused by a lack of technical skills for dealing with climatically difficulties and by damage resulting from wars between local warlords. In such a situation of stagnation the dominant values refer to communitarians and collectivism; the group as protection against the outside world. The lack of sight on any progress leads to fatalism and an orientation on the past instead.

The religion was more than a set of behavior and would affect family life. Most parents and some young people a religious way of life is transmitted between generation and grandparent maintain a significant influence. Respect is extremely valued components of the everyday life o people in India.childern are thought from a very young age to always respect their elders. Children take care of their parents will most likely live with them until lives have ended.

The importance of the family in making and molding an individual on the one hand, and influencing social groups and patterns on the other, has been recognized by social scientists. The present study focuses on individual level changes affected by the modifications that are taking place in the family under rapid on-going socio-cultural changes in contemporary Indian society.

Family is the basic and universal social structure of human society. It fulfils needs and performs functions, which are indispensable for the continuity, integration and change in the social system. The family may be broadly perceived as a unit of two or more persons united by the ties of marriage, blood, adoption or consensual unions. It is considered the basic unit of the society, to meet the needs of individuals and those of other societal institutions. It determines the development of individuals, in that; it is a major source of nurturance, emotional bonding and socialization. In contemporary urban society, families present a peculiar combination of traditional and modern values

- Religious: - believing in God or a group of Gods and following the rules of religion. 
- Religious is a cultured system of behavior and practices, world views, ethics and social organization that relate humanity to an order of existence.

- The belief in and worship of a super human controlling power, especially a personal God.

- The service and worship of God or the super-natural.

- A personal set or institutionalized system of religious attitude, beliefs and practices.

\section{MEANING OF THE RELIGION}

Religion is a fundamental set of beliefs and practices generally a agreed upon by group of people. These set of beliefs concern the cause, nature and purpose of the universe and involve denationalize and ritual observation. They also often contain a moral code governing the conduct of human affairs.

There are several founding principal of common value in Indian culture these include:

* Tyaga- Renunciation- Tyāga (Sanskrit: त्याग) is derived from त्यज् - meaning risking one's life or giving up one's person. ${ }^{[1]}$ Tyāga means - sacrifice, renunciation, abandonment, resignation, donation, forsaking, liberality, withdrawal ${ }^{[2]}$ Tyāga which is not merely physical renunciation of the world is different from Sannyasa; Sannyasa which comes from the root as means - "giving up entirely", Tyāga means "giving up with generosity what one could probably have kept"

* Dana-Liberal giving- Dāna (Sanskrit: दान) means giving, often in the context of donation and charity. ${ }^{[8]}$ In other contexts, such as rituals, it can simply refer to the act of giving something. ${ }^{[8]}$ Dāna is related to and mentioned in ancient texts with concepts ofParopakāra (परोपकार) which means benevolent deed, helping others ${ }^{[9][10]}$ Dakshina (दक्षिणा) which means gift or fee one can afford; ${ }^{[11][12]}$ and Bhiksha (भिक्षा), which means alms. ${ }^{[13][14]}$

Dāna has been defined in traditional texts as any action of relinquishing the ownership of what one considered or identified as one's own, and investing the same in a recipient without expecting anything in return. ${ }^{[15]}$ While dāna is typically given to one person or family, Hinduism also discusses charity or giving aimed at public benefit, sometimes called utsarga. This aims at larger projects such as building a rest house, school, drinking water or irrigation well, planting trees, and building care facility among others

* Nishtha- Dedication -Nishtha (Sanskrit: निष्ठ or निष्ठा) means - 'being in or on', 'situated on', 'depending or 'resting on', 'referring' or 'relating to', 'devoted or attached to', 'practicing', 'intent on', 'skilled in', 'believing in', 'conducive to', 'effecting', 'position', 'condition', 'state', 'basis', 'foundation', 'fixity', 'fixedness', 'steadiness', 'devotion', 'application', 'close attachment', 'belief', 'firm adherencev, 'faith', 'excellence', 'skill', 'proficiency', 'perfection', conclusion', 'end', 'termination', 'the catastrophe or end of a drama', 'accomplishment', 'completion', 'the culminating point', 'death', 'destruction', 'disappearance from the world at the fixed time', 'fixed or certain knowledge', 'certainty', 'begging', 'suffering', 'trouble', 'distress', 'anxiety', 'a technical term for past participial terminations', and is one of the many names of Vishnu-

* Satya-Truth- atya is the Sanskrit word for truth. ${ }^{[3][4]}$ It also refers to a virtue in Indian religions, referring to being truthful in one's thought, speech and action. ${ }^{[5]}$ In Yoga, satya is one of five yamas, the virtuous restraint from falsehood and distortion of reality in one's expressions and actions

* Ahimsa-Non-Violence- Ahinsa (Sanskrit: अहिंसा; IAST: ahimsā, Pāli: ${ }^{[1]}$ avihiṃsā) is a term meaning 'not to kill' and 'compassion'. The word is derived from the Sanskrit root hims - to strike; himsā is injury or harm, $a$-hims $\bar{a}$ is the opposite of this, i.e. cause no injury, do no harm. ${ }^{[2][3]}$ Ahimsa is also referred to as nonviolence, and it applies to all living beings - including all animals - according to many Indian religions. $^{[4]}$

Ahimsa is one of the cardinal virtues ${ }^{[5]}$ and an important tenet of 3 major religions (Jainism, Hinduism, and Buddhism). Ahimsa is a multidimensional concept, ${ }^{[6]}$ inspired by the premise that all living beings have the spark of the divine spiritual energy; therefore, to hurt another being is to hurt oneself. Ahimsa has also been related to the notion that any violence haskarmic consequences. While ancient scholars of Hinduism pioneered and over time perfected the principles of Ahimsa, the concept reached an extraordinary status in the ethical philosophy of Jainism. ${ }^{[5][7]}$ Most popularly, Mahatma Gandhi strongly believed in the principle of ahimsa. ${ }^{[8]}$

Ahimsa's precept of 'cause no injury' includes one's deeds, words, and thoughts. ${ }^{[9][10]}$ Classical literature of Hinduism such as Mahabharata and Ramayana, as well as modern scholars ${ }^{[11]}$ debate principles of Ahimsa when one is faced with war and situations requiring self-defense. The historic literature from India and modern discussions have contributed to theories of Just War, and theories of appropriate self-defense.

* Upeksha-Forbearance - Upeksha in Sanskrit or Upekkha in Pali means equanimity, non-attachment, nondiscrimination, even-mindedness or letting go. Upeksha does not mean indifference. It is the fourth element of true love and has as its seed the wisdom of equality that removes all boundaries, discrimination and prejudices while leading to the sublime unity where there is no self and no other; without Upeksha, love becomes possessive. ${ }^{[1]}$ Equanimity or Upeksha grows out of mindfulness, then one becomes master of every 
situation no matter what the situation is without it one cannot take anything in one's stride, its significance is that one really lives unconditionally, ${ }^{[2]}$

The understanding that our happiness and that of others is inseparable moves us directly into the fourth Brahmavihara, Upeksha. Equanimity of Upeksha carries the ability to take a large view and to look over the whole situation not bound by one side or the other, its near-enemy is in-difference which is difficult to recognize because it masquerades on the surface as even-mindedness; indifference causes retreat to a form of denial like repression, don't care-can't be bothered attitude

Religious values center on the expectations that people have about themselves and others based on the beliefs of their faith. Although each faith has its beliefs, there are common values that many faiths tend to share. Examples of religious values include:

- Showing compassion to those in need

- Treating others as one would like to be treated

- Continually learning and growing both spiritually and intellectually

- Being modest in your relations with others

- Being respectful and nonviolent when interacting with others

Family values involve all of the ideas of how you want to live your family life and they are often passed down from previous generations. They can help define behavior in various situations help youth make good choose and solidify the bond that your family.

\section{TYPES OF VALUES}

Social values

$>$ Political values

$>$ Work values

$>$ Moral values

$>$ Recreational values

> Social values- Social values form an important part of the culture of the society. Values account for the stability of social order. They provide the general guidelines for social conduct. Values such as fundamental rights, patriotism, respect for human dignity, rationality, sacrifice, individuality, equality, democracy etc. guide our behavior in many ways. Values are the criteria people use in assessing their daily lives; arrange their priorities and choosing between alternative courses of action. Values provide for stabilities and uniformities in group interaction. They hold the society together because they are shared in common. The rule are accepted as rules and followed mainly because they embody the values that most people accept.

> Political values- It refers to a learning process by which norms and behavior acceptable to a well running political system are transmitted from one generation to another. It is through the performance of this function that individuals are inducted into the political culture and their orientations towards political objects are formed. These factors and many others that people are introduced to as they grow up will affect their political views throughout the rest of their lives. Political beliefs are often formed during childhood, as parents pass down their ideologies to their children and so on. Family as a primary influence in the development of a child's political orientation, mainly due to constant relationship between parents and child. Family is most important shaper of basic attitudes; teaches basic political values \& loyalty to particular political party through family members. Schools is Most influential of all agents, after the family, due to the child's extended exposure to a variety of political beliefs, such as friends and teachers, both respected sources of information for students. The media functions as a medium of political information to adolescents and young children. Religious tradition can have a strong effect on someone's political views.

Work values- A value is a principal or standard that is held in high esteem by an individual and is related to all aspects of one's personal and work life. You may have values around family, work, spiritual, leisure, personal, etc. In this exercise you will focus on your work values. As you rank each value, think about how important the value is to you in a work setting. As you consider your work related values, keep in mind that there are no right or wrong work values; rather it is a process of identifying what matters most to you rather than someone else. Your work values are the work-related qualities, principles and standards that really matter to you. When your career path and the type of work you do are in line with your values, your work is likely to be more satisfying and rewarding. If you're currently doing some career and education planning, identifying your work values lets you clarify your goals and move in a direction that will help you achieve 
them. If you're currently employed, reviewing your work values regularly will help you manage the inevitable changes in your workplace and life situation.

\section{Work related values}

Opportunity to focus on both your work and life roles

- Common work -related values

- Balance

- Being an expert

- Belonging

- Challenge

- Competition

- Creativity

- Decision-making

- Flexibility

- Innovation

- Satisfaction

- Security

- Status

> Moral values -Moral values the standard of good and evil, which govern an individual's behavior and choices. Individual's moral may derive from society and govt. religion or self. Moral values are relative values that protect life and are respectfully of the dual life value, such as truth, freedom, charity ect, have one thing in common. Moral have a greater social element to values and tend to have a very broad acceptance. Moral are for more about good and bad than other values. Moral values are very important part of the family .our values and moral are a reflection of our spirituality our character. Value education means inculcating in the children sense humanism a deep concern for the well being of others and the nation. Good moral values allow a person of make the right decisions and improve their interaction with other people.

Moral values are your individual values about what you think is right and wrong. Moral values provide the foundation from which you make decisions. Moral values are learned from your parents and your experiences. Examples of moral values include:

- Being honest and trustworthy

- Being courageous

- Never giving up

- Adding value to the world

- Being patient

- Taking personal responsibility

\section{$>$ Recreational values}

Recreation refers to community-based educational or sports activities that contribute to the overall development of individuals and the ability of citizens to take charge of their local community Thus, recreation has a value for individuals and groups and also constitutes a means of improving the functioning of societies. These views are in line with the findings of many studies. In his meta-analysis of studies on the effects of recreation on young people, recreation has positive spin-offs for the social relationships between adolescents and their peers and teachers. Recreation has an impact on the behavior of young people with regard to the prevention or reduction of negative behavior, stress and petty crime, alcohol or drug consumption, and eating disorders. Recreation can also stimulate the adoption or maintenance of positive behaviors such as involvement in volunteer activities and peer and mutual support, as well as increased self-esteem, and it has positive effects on social participation, social cohesion, and in intercultural understanding.

Recreational values refer to anything that involves fun and play. Recreation is important in the family because it fosters closeness in the family, opportunities for learning, creating memories, improving social skills, and developing empathy. Examples of recreational values include:

- Providing unstructured play time

- Having family game nights

- Allowing and encouraging each family member to pursue interests

- Taking vacations together

- Spending time together outside playing 


\section{CONCLUSION}

Values drive behavior and resources allocation believing that each individual has a particular value orientation, it could be said that the value orientation identifies the human being "view toward society" and their interaction and behavior to others economic status, educational level and life expectancy feeling as socioeconomic indicators of human .While they may have never identified their values, all of sudden they are faced with the realization that something doesn't quite fit into what they believe in. This is when people realize how important family values are to the structure and operation of their family system. Values influence the decisions people make both within the family structure and outside of it. Making a decision about important topics can be difficult and helps people make the right decisions in life.

\section{REFERENCES}

[1]. J. Delor, Education: The Necessary Utopia (Introduction of the Delors Report), (1996), UNESCO Task Force on Education for the 21st century.

[2]. J. Delor, Learning: The Treasure Within, (2011), UNESCO Commission on Education in the 21st Century.

[3]. G. Lopez, Putting new bite into knowledge, in I. Serageldin et al. (eds), Organising Knowledge for Environmentally and Socially Sustainable Development, (1997), The World Bank, Washington DC.

[4]. P. Lamy, WTO Director-General, Speech to the European University Institute in Florence on 19 February, (2011), Available at: http://www.wto.org/ english/news_e/sppl_e/sppl187_e.htm.

[5]. M. Massey, Learning: The Treasure Within, (2011), UNESCO, in J. Delor, Ibid.

[6]. Wikipedia, The free Encyclopedia, http://www.wikipediaencycloppedia.org/english. WCED, Our common future, Seminar World Commission in Environmental Development, (1987).

[7]. W. Wyatt, Learning: The Treasure Within, (2011), UNESCO, in J. Delor, Ibid.

[8]. J.W. Santrock, A Topical Approach to Life-Span Development, (2007), New York, NY: McGraw-Hill.

[9]. Rausser, G. and Small, A. (2000), "Valuing research leads: bioprospecting and the conservation of genetic

[10]. resources", Journal of Political Economy 108(1):173-206

[11]. Ricker, M., Mendelssohn, R.O., Daly, D.C., and Angeles, G. (1999), "Enriching the rainforest with native fruit

[12]. trees: an ecological and economic analysis in Los Tuxtlas (Veracruz, Mexico)", Ecological Economics, 31(3):439448

[13]. Ricketts, T.H., Daily, G.C., Ehrlich, P.R., and Michener, C.D. (2004), "Economic value of tropical forest to

[14]. Coffee production", Proceedings of the National Academy Science 101(34):12579-12582.

[15]. Robbins, C.S. (1992), "Comparison of Neotropical Migrant Bird Populations Wintering in Tropical Forest,

[16]. Isolated Fragements, and Agricultural Habitats", Smithsonian Institution Press, Washington D.C.

[17]. Roubik, D. W. (2000), "Pollination system stability in tropical America", Conservation Biology, 14(5):1235-1236.

[18]. Ruitenbeek, H.J. (1994), "Modelling economy ecology linkages in mangroves - economic evidence for

[19]. Promoting conservation in Bintuni Bay, Indonesia", Ecological Economics, 10(3):233-247.

[20]. Ruitenbeek, H.J. (1989), "Social Cost-Benefit Analysis of the Korup Project, Cameroon", prepared for the

[21]. World Wide Fund for Nature and the Republic of Cameroon.

[22]. Andrews, A. R. 1979. "Religion, Psychology, and Science: Steps Toward a Wider Psychology of Religion." Journal of Psychology and Theology7 (1): 31-38.

[23]. Bahr, H. M., and B. Chadwick. 1985. "Religion and Family in Middletown, USA." Journal of Marriage and the Family 47 (May): 407-14.

[24]. Beit-Hallahmi, B. 1974. "Psychology of Religion in 1880-1930: The Rise and Fall of a Psychological Movement." Journal of the History of the Behavioral Sciences 10: 84-94.

[25]. Bergin, A. E. 1980. "Psychotherapy and Religious Values." Journal of Consulting and Clinical Psychology 48 (1): 95-105.

[26]. Bergin, A. E. 1983. "Religiosity and Mental Health: A Critical Reevaluation and Meta-analysis." Professional Psychology: Research and Practice 14 (2): 170-84.

[27]. Brinkerhoff, M. B., and M. Mackie. 1985. "Religion and Gender: A Comparison of Canadian and American Student Attitudes." Journal of Marriage and the Family 47 (May): 415-29.

[28]. Burr, W. R., R. Hill, F. I. Nye, and I. L. Reiss. (Eds.) 1979. Contemporary Theories About the Family (2 vols.). New York: The Free Press.

[29]. Caplow, T, H. M. Bahr, B. A. Chadwick, R. Hill, and M. H. Williamson. 1982. Middletown Families: Fifty Years of Change and Continuity. Minneapolis: University of Minnesota Press.

[30]. Salafsky, N. and Wallenberg, E. (2000), "Linking livelihoods and conservation: a conceptual framework and

[31]. Scale for assessing the integration of human needs and biodiversity", World Development, 28(8):1421-1438. 